\title{
ASSOCIATION BETWEEN INTERLEUKIN-10 GENE (-1082G/A) POLYMORPHISM AND TYPE 2 DIABETES, DIABETES-RELATED TRAITS, AND MICROVASCULAR COMPLICATIONS IN THE CROATIAN POPULATION
}

\author{
Silvija Canecki-Varžić ${ }^{1}$, Ivana Prpić-Križevac ${ }^{1}$, Silvio Mihaljevićé Ines Bilić-Ćurčić ${ }^{1}$,

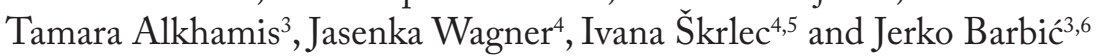

${ }^{1}$ Department of Diabetes, Endocrinology and Metabolism Disorders, Osijek University Hospital Centre, Faculty of Medicine, Josip Juraj Strossmayer University of Osijek, Osijek, Croatia; ${ }^{2}$ Department of Gastroenterology and Hepatology, Osijek University Hospital Centre, Faculty of Medicine, Josip Juraj Strossmayer University of Osijek, Osijek, Croatia; ${ }^{3}$ Department of Pathophysiology, Faculty of Medicine, Josip Juraj Strossmayer University of Osijek, Osijek, Croatia; ${ }^{4}$ Department of Medical Biology and Genetics, Faculty of Medicine, Josip Juraj Strossmayer University of Osijek, Osijek, Croatia; ${ }^{5}$ Faculty of Dental Medicine and Health, Josip Juraj Strossmayer University of Osijek, Osijek, Croatia; ${ }^{6}$ Department of Nephrology and Dialysis, Osijek University Hospital Centre, Faculty of Medicine, Josip Juraj Strossmayer University of Osijek, Osijek, Croatia

SUMMARY - Interleukin (IL)-10 is an anti-inflammatory cytokine, and a decrease in its secretion is associated with obesity, metabolic syndrome and type 2 diabetes. However, it has not been established whether the intensity of the immune response during diabetes-associated chronic inflammation affects the development and/or progression of type 2 diabetes and its microvascular complications. The aim of this study was to investigate the role of single nucleotide polymorphism (SNP)-1082G/A for IL-10 gene in development of diabetes type 2 and its complications. DNA was extracted from blood cells of 240 overweight/obese subjects for IL-10 genotyping. Based on the presence of diabetes type 2, patients were divided in two groups: experimental group of 144 patients with diabetes type 2 and control group of 96 age- and gender-matched subjects without diabetes. Compared to control group, diabetic group had higher levels of leukocytes $(\mathrm{p}=0.012)$, fibrinogen $(\mathrm{p}=0.049)$ and plasminogen activator inhibitor-1 (PAI-1) $(\mathrm{p}=0.009)$, and lower levels of albumin $(\mathrm{p}=0.001)$. There were no differences in the frequency of SNP-1082G/A for IL-10 gene between the two groups $(\mathrm{p}=0.654)$. When considering diabetes related traits in all subjects in relation to specific genotype, a group with homozygous (AA) genotype had higher values of the mean fasting glucose $(\mathrm{p}<0.000001)$, HbA1c $(\mathrm{p}<0.000001)$ and HOMA-IR $(\mathrm{p}=0.003632)$, while the mean HOMA-B value ( $\mathrm{p}=0.000178)$ was lower when compared to the groups with GG and GA genotypes. There was no difference in development of diabetic nephropathy, retinopathy and polyneuropathy between the IL-10 polymorphism genotypes. In conclusion, obese diabetes type 2 patients had an increased inflammation activity compared to obese non-diabetic individuals. There was no association of the investigated polymorphisms and development of type 2 diabetes and its microvascular complications. However, diabetes related traits clearly depended on the presence of specific IL-10 genotype.

Key words: Type 2 diabetes; Inflammation; Interleukin-10; Single nucleotide polymorphism-1082G/A; Microvascular complications

\section{Introduction}

Hypersecretion of proinflammatory cytokines (tumor necrosis factor- $\alpha$, interleukin (IL)-1, and IL-6) in overweight and obese individuals can cause insulin re-
Correspondence to: Ivana Prpić-Križevac, MD, Department of Diabetes, Endocrinology and Metabolism Disorders, Osijek University Hospital Centre, Faculty of Medicine, Josip Juraj Strossmayer University of Osijek, J. Huttlera 4, HR-31000 Osijek, Croatia E-mail: prpic-krizevac.ivana@kbco.hr

Received October 16, 2017, accepted February 19, 2018 
sistance in peripheral tissues ${ }^{1-4}$, as well as a decline in beta cell mass and function ${ }^{5-7}$, thus promoting development of type 2 diabetes. Presumably, this effect can be countered by anti-inflammatory cytokines such as IL-10, transforming growth factor- $\beta$, and adiponec$\operatorname{tin}^{8-12}$. Hence, the possibility exists that an imbalance in the activity of pro- and anti-inflammatory cytokines has an important role in the pathogenesis of type 2 diabetes.

Polymorphisms in pro- and anti-inflammatory cytokine genes, as well as their receptors, may exacerbate this cytokine imbalance and thus also development of type 2 diabetes ${ }^{13-16}$. On the basis of genotype, there are 'high' and 'low'cytokine producers. By identifying specific polymorphisms in each cytokine gene, it is possible to identify high and low cytokine producers by genotype. Therefore, in certain individuals, a genetic predisposition for a hyper-reactive immune response may be responsible for the development of type 2 diabetes. Furthermore, the progression of microvascular complications $^{16-18}$ may be associated with polymorphisms in pro- and anti-inflammatory cytokine genes. However, it has not been established whether the intensity of the immune response during diabetes-associated chronic inflammation affects the development and/or progression of type 2 diabetes and its characteristic microvascular complications.

Interleukin-10 is a primary anti-inflammatory cytokine, and according to previous reports, a decrease in its secretion is associated with obesity and metabolic syndrome, as well as hyperglycemia and type 2 diabetes ${ }^{8,9,13,19}$. The IL-10 gene is located in the $1 \mathrm{q} 32.1 \mathrm{~h}$ genomic region. Within this region, a point mutation $(\mathrm{G}$ to $A)$ at position -1082 is linked to low IL-10 expres$\operatorname{sion}^{13,19,20}$. The objective of this study was to determine the frequency of the IL-10 gene polymorphism, $-1082 \mathrm{G} / \mathrm{A}$, in overweight/obese patients with type 2 diabetes compared to overweight/obese non-diabetic controls, and to determine the possible link between this polymorphism and the fundamental pathophysiological complications of type 2 diabetes such as insulin resistance, reduced beta cell function, and microvascular dysfunction.

\section{Materials and Methods}

\section{Study design}

This was a cross-sectional study that included 240 subjects. The experimental group consisted of 144 overweight or obese patients with type 2 diabetes, and the control group included 96 age- and sex-matched overweight or obese individuals without type 2 diabetes. Subjects were recruited from the outpatient population visiting Regional Center for Endocrinology and Metabolism Disorders, Osijek University Hospital Centre in Osijek and primary care physician practices in the Osijek-Baranja County, Croatia from 2010 to 2013. This study complied with the Declaration of Helsinki and was approved by the Ethics Committee of the Osijek University Hospital Centre (reference number 29-1:6663/06). A written informed consent was obtained from each patient.

\section{Patient inclusion criteria}

The experimental group was required to meet the following inclusion criteria: diagnosis of type 2 diabetes; diabetes treated with diet, exercise, or medications (not thiazolidinediones or insulin therapy); excessive body weight (body mass index $(\mathrm{BMI})>25 \mathrm{~kg} / \mathrm{m}^{2}$ ); and age 18-80 years. In the control group, type 2 diabetes was excluded based on the fasting glucose $(<7 \mathrm{mmol} / \mathrm{L})$ and glycated hemoglobin (HbA1c; $<6.5 \%)$ levels, according to the recommendations of the American Diabetes Association, International Diabetes Federation, and European Association for the Study of Diabetes. Patients with a history of the following conditions were excluded from the study: type 1 diabetes; diabetes treated with insulin therapy; recent acute infection regardless of localization; long-term treatment with immunomodulatory and anti-inflammatory drugs; long-term therapies with possible pro-diabetic effects such as glucocorticoids, immunosuppressive drugs, and certain antidepressants used over a period of 3 months; endocrine disorders with secondary diabetes; other intercurrent diseases associated with acute or chronic inflammation; history of acute pancreatitis or chronic pancreatitis; history of acute or chronic $\mathrm{B}$ or $\mathrm{C}$ hepatitis or HIV; or malignant disease within the past 5 years.

\section{Methods}

At study entry, medical history was obtained that included demographics, family history, disease diagnosis, risk factors for type 2 diabetes, presence of chronic complications, other relevant diseases, medications, and lifestyle habits. Physical examination was per- 
formed with standardized measurement of body weight, body height, waist circumference, and blood pressure. BMI was calculated from body weight and height $\left(\mathrm{kg} / \mathrm{m}^{2}\right)$. In addition, blood and urine samples were collected for biochemical analyses (fasting glucose, $\mathrm{HbA} 1 \mathrm{c}$, liver enzymes, lipid profile, creatinine, uric acid, total proteins, albumins, leukocytes, C-reactive protein $(\mathrm{CRP})$, plasminogen activator inhibitor-1 [PAI-1], and fibrinogen), evaluation of complications (endogenous creatinine clearance, 24-hour urine protein, and 24-hour urine albumin excretion), hormone analysis (insulin, C-peptide, thyroid-stimulating hormone (TSH), cortisol, sex hormone binding globulin (SHBG)), and DNA isolation, to determine the presence and effects of the gene polymorphism. All patients underwent neurological and ophthalmological examinations. Biochemical and urine analyses were performed using established methods in the Central Laboratory of the Osijek University Hospital Centre.

To assess glucose metabolism, the following parameters were chosen: fasting glucose, $\mathrm{HbA} 1 \mathrm{c}$, insulin, $\mathrm{C}$-peptide, homeostatic model assessment index of insulin resistance (HOMA-IR), and homeostatic model assessment index of beta cell function (HOMA-B). HOMA-IR and HOMA-B were calculated using the following formulae: HOMA-IR = glucose $(\mathrm{mmol} / \mathrm{L})$ $\times$ insulin $(\mathrm{mIU} / \mathrm{L}) / 22.5 ; \mathrm{HOMA}-\mathrm{B}=20 \times$ insulin (mIU/L)/(glucose - 3.5)\%.

All samples for hormone analysis were centrifuged and frozen at $-20{ }^{\circ} \mathrm{C}$. Hormone levels (insulin, C-peptide, cortisol, TSH and SHBG) were determined using the radioimmunoassay method with commercially available kits, according to the manufacturer's recommendations (DIAsource Immuno Assays S.A., Louvain-la-Neuve, Belgium).

Genomic DNA was extracted from $200 \mu \mathrm{L}$ of peripheral whole blood with EDTA as an anticoagulant. Commercially available spin columns for DNA extraction were used for DNA extraction, according to the manufacturer's instructions (G-spin TN Genomic DNA Extraction Kit; Intron Biotechnology, Seoul, South Korea).

Genotypic analysis of the IL-10 gene polymorphism, -1082G/A (rs1800896), was performed using TaqMan ${ }^{\circledR}$ SNP Genotyping Assay (Assay ID: C__7514879_10) with an ABI PRISM 7000 Sequence Detection System (Applied Biosystems, Foster City, CA, USA).
Thermocycler parameters were as follows: $95^{\circ} \mathrm{C}$ for $10 \mathrm{~min}$ (hold); 40 cycles at $92{ }^{\circ} \mathrm{C}$ for $15 \mathrm{~s}$ (denaturation), $60{ }^{\circ} \mathrm{C}$ for $1 \mathrm{~min}$ (primer annealing and extension). Negative and positive control samples were run simultaneously in each real-time PCR plate analyzed. The total reaction volume per well was $25 \mu \mathrm{L}$ with 5 $\mu \mathrm{L}$ of DNA $(1 \mathrm{ng} / \mu \mathrm{L})$ used as a template.

\section{Statistical analysis}

Results were analyzed using descriptive statistical analysis. Continuous variables were summarized using sample size, mean, median, standard deviation, and minimum and maximum values. Significance was declared at a two-sided 0.05 level, unless otherwise specified. Student's $t$-test was used as a parameter test and Mann-Whitney as a non-parameter test to calculate distribution differences for continuous variables. The $\chi^{2}$-test and Fisher exact tests were used for variables measured by a nominal or ordinal scale. To detect differences in the distributions of three or more variables, the ANOVA test (parameter test) and Friedman ANOVA test (non-parameter test) were utilized. In addition, factorial analysis of variables was used in which one variable was a specific group (experimental or control), and the other was the cytokine genotype. The Hardy-Weinberg equilibrium (deviation of expected genotype frequencies $-\mathrm{p}^{2}+2 \mathrm{pq}+\mathrm{q}^{2}$, where $\mathrm{pq}$ represents the frequency of one of two possible alleles, biallelic single nucleotide polymorphism (SNP)) was tested with the $\chi^{2}$-test with one degree of freedom and significance at $\mathrm{p}<0.05$. Statistical analysis was performed using Statistica 9.1 (StatSoft Inc., Tulsa, OK, USA, 2012).

\section{Results}

The baseline characteristics of the subjects are summarized in Table 1 . Both groups were similar in age and sex. Body weight ( $\mathrm{p}=0.012), \mathrm{BMI}(\mathrm{p}=0.018)$, and waist circumference ( $p=0.026)$ were significantly higher in the controls when compared to patients with diabetes. Fasting glucose and $\mathrm{HbA} 1 \mathrm{c}$ values were higher ( $\mathrm{p}<0.00001$ and $\mathrm{p}<0.00001$, respectively) in patients with type 2 diabetes, while insulin and $\mathrm{C}$-peptide values were similar in both groups. HOMA-IR was significantly higher $(\mathrm{p}=0.000083)$ and HOMA-B $(\mathrm{p}=0.022)$ significantly lower in diabetic group than in 
Table 1. Baseline characteristics of study subjects

\begin{tabular}{|l|l|l|l|}
\hline Baseline characteristic & $\begin{array}{l}\text { Type 2 diabetes } \\
(\mathrm{n}=143)\end{array}$ & $\begin{array}{l}\text { Control } \\
(\mathrm{n}=96)\end{array}$ & p-value \\
\hline Age (years) & $60.1 \pm 10.3$ & $58.8 \pm 8.4$ & $\mathrm{NS}$ \\
Age at diagnosis (years) & $52.1 \pm 11.4$ & $30(32)$ & 0.000001 \\
Sex: male, $\mathrm{n}(\%)$ & $63(44)$ & $60(68)$ & $\mathrm{NS}$ \\
$\quad$ female, $\mathrm{n}(\%)$ & $80(56)$ & $95.9 \pm 20.8$ & 0.056 \\
Body weight $(\mathrm{kg})$ & $89.1 \pm 19.6$ & $34.04 \pm 6.43$ & 0.012 \\
Body mass index (kg/m $\left.{ }^{2}\right)$ & $32.17 \pm 5.49$ & $107.5 \pm 13.8$ & 0.018 \\
Waist circumference $(\mathrm{cm})$ & $103.4 \pm 12.8$ & $140 \pm 18$ & 0.026 \\
Systolic blood pressure $(\mathrm{mm} \mathrm{Hg})$ & $135 \pm 18$ & $86 \pm 9$ & 0.04 \\
Diastolic blood pressure $(\mathrm{mm} \mathrm{Hg})$ & $83 \pm 11$ & $5.1 \pm 0.7$ & $\mathrm{NS}$ \\
Fasting glucose (mmol/L) & $10.5 \pm 4,2$ & $5.86 \pm 0.28$ & $<0.00001$ \\
HbA1c (\%) & $9.37 \pm 2.35$ & $12.99(8.8-17.8)^{*}$ & $<0.00001$ \\
Insulin (mIU/L) & $14.17(7.17-15,2)^{*}$ & $\mathrm{NS}$ \\
C-peptide (pmol/L) & $1,106.7 \pm 559.1$ & $1,192.8 \pm 596.8$ & $\mathrm{NS}$ \\
HOMA-IR & $4.60(3.35-6.3)^{*}$ & $3.52 \pm 2.71$ & 0.00008 \\
HOMA-B & $30.09(17.7-76,5)^{*}$ & $210.4 \pm 126.7$ & 0.022 \\
Cholesterol (mmol/L) & $5.34 \pm 1.58$ & $6.19 \pm 1.38$ & 0.00037 \\
Triglycerides (mmol/L) & $2.07(1.58-2.67)^{*}$ & $1.83 \pm 1.05$ & 0.014 \\
HDL cholesterol (mmol/L) & $1.19 \pm 0.49$ & $1.35 \pm 0.34$ & 0.0045 \\
LDL cholesterol (mmol/L) & $3.08 \pm 1.24$ & $4.06 \pm 1.18$ & $<0.00001$ \\
L ( $\times 109$ cells/L) & $7.2 \pm 2.2$ & $6.5 \pm 1.7$ & 0.012 \\
CRP (mg/L) & $3.0(1.3-5.6)^{*}$ & $3.1(1.4-7.2)^{*}$ & $\mathrm{NS}$ \\
Fibrinogen (g/L) & $3.93 \pm 1.06$ & $3.70 \pm 0.84$ & 0.049 \\
PAI-1 (U/L) & $4.19 \pm 1.82$ & $3.49 \pm 1.99$ & 0.009 \\
Albumin (g/L) & $42.60 \pm 3.43$ & $44.13 \pm 2.70$ & 0.001 \\
\hline
\end{tabular}

t-test; NS = nonsignificant; HOMA-IR = homeostatic model assessment index of insulin resistance; HOMA-B = homeostatic model assessment index of beta-cell function; HDL = high-density lipoprotein; LDL = low-density lipoprotein; $\mathrm{L}=$ leukocytes; $\mathrm{CRP}=\mathrm{C}$-reactive protein; $\mathrm{PAI}-1$ = plasminogen activator inhibitor-1; *values represented as median (interquartile range)

control group. Lipid profile analysis revealed that triglyceride levels were higher $(p=0.014)$ in diabetic group, while high-density lipoprotein $(\mathrm{p}=0.0045)$, low-density lipoprotein cholesterol $(\mathrm{p}<0.00001)$ and total cholesterol levels ( $\mathrm{p}=0.00037)$ were lower in $\mathrm{pa}^{-}$ tients with diabetes than in control group, most likely as a consequence of treatment with statins in the former. Diabetic group had higher levels of leukocytes $(\mathrm{p}=0.012)$, fibrinogen $(\mathrm{p}=0.049)$ and PAI-1 $(\mathrm{p}=0.009)$, and lower levels of albumin $(\mathrm{p}=0.001)$ than control group. CRP levels were also higher in patients with diabetes, but the difference was only numerical and not statistically significant.
Investigation of IL-10 gene polymorphisms revealed that genotypes did not significantly deviate from Hardy-Weinberg equilibrium (IL-10-1082G/A (rs1800896); $\mathrm{p}=0.941$ ) indicating that in the experimental population, the effects of selection, genetic drift, mutations, gene flow, and migration were not present. The frequency of the minor allele was 0.427 (42.7\%) in all subjects. The IL-10-1082G/A genotype distribution in diabetic group was as follows: GG homozygous, 29.37\%; GA heterozygous, 55.94\%; and AA homozygous, $14.69 \%$. The genotype distribution in control group was as follows: GG homozygous, 32.29\%; GA heterozygous, 50.0\%; and AA homozygous, $17.71 \%$. 
a)

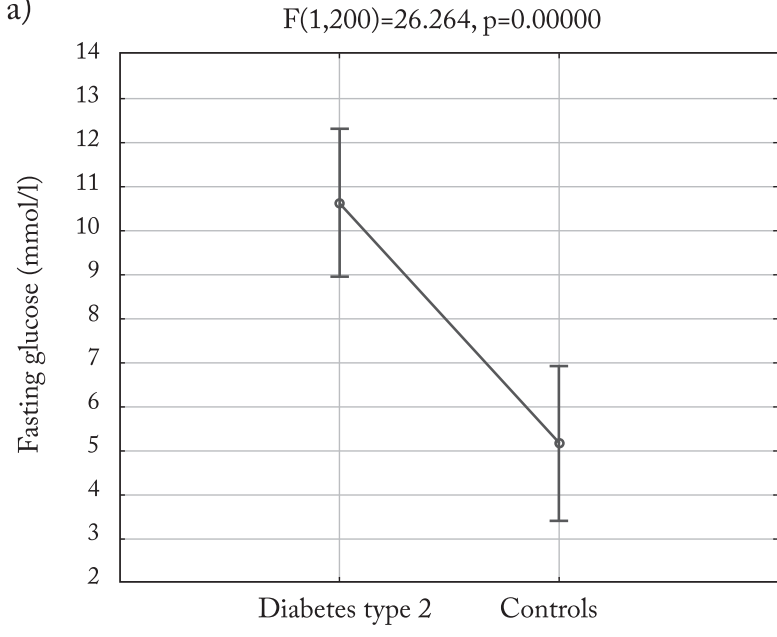

c)

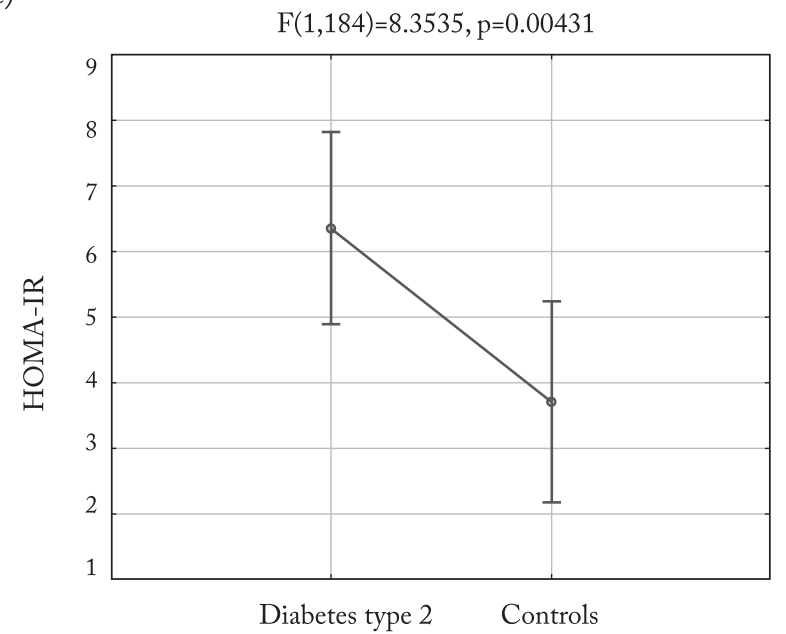

b)

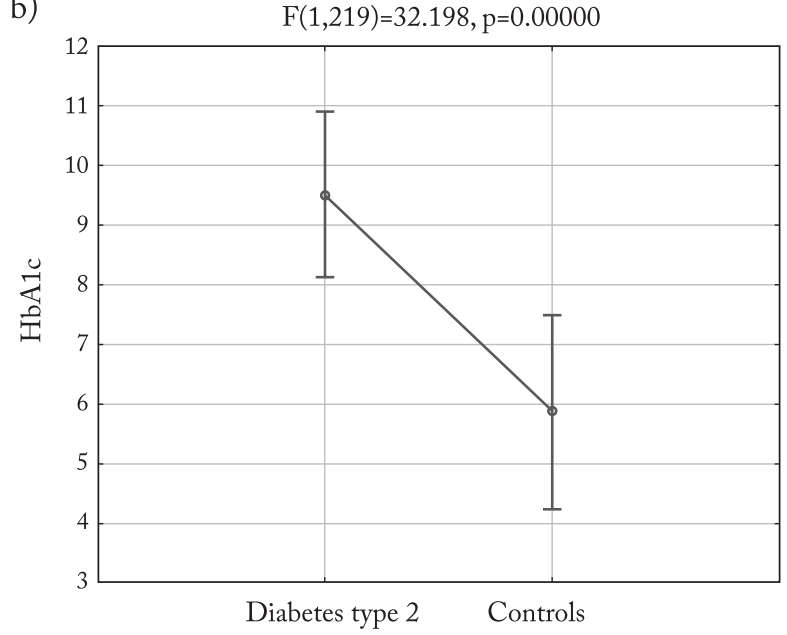

d)

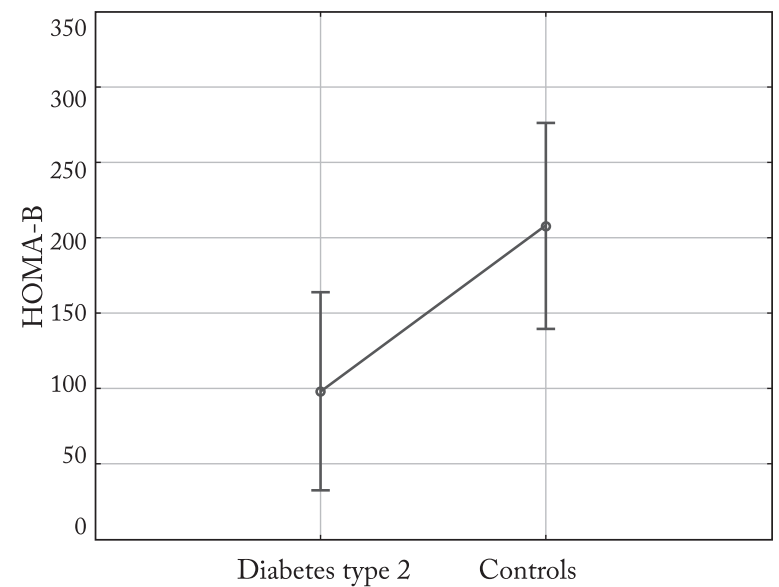

Fig. 1. Mean values of fasting glucose (a), HbA1c (b), HOMA-IR (c) and HOMA-B (d) in diabetes type 2 group and control group.

There was no significant difference in genotype distribution between the two groups $(\mathrm{p}=0.654)$.

In order to evaluate the effect of the IL-10 genotype on glucose metabolism, the mean values of fasting glucose, HbA1c, HOMA-IR and HOMA-B were first compared between the diabetic and control groups (Fig. 1). These values were then compared between different IL-10 genotypes including all subjects (experimental and control) (Fig. 2), and finally with the genotype and group affiliation combined (Fig. 3). The mean levels of fasting glucose $(\mathrm{p}<0.000001), \mathrm{HbA} 1 \mathrm{c}$ $(\mathrm{p}<0.000001)$ and HOMA-IR $(\mathrm{p}=0.004312)$ were significantly higher, while the mean HOMA-B $(p=0.047508)$ levels were lower in patients with diabetes than in controls, as expected (Fig. 1). Analysis of the mean fasting glucose and $\mathrm{HbA} 1 \mathrm{c}$ levels in subjects with the AA genotype ('low producers' of IL-10) yielded significantly higher values $(\mathrm{p}<0.000001)$ of both parameters in control and diabetic subjects. Antiinflammatory effects were expected to be lowest in this group (Fig. 2). The interaction effect was not statistically significant, indicating that the effect of a specific IL-10 genotype on the phenotype, in this case fasting glucose and $\mathrm{HbA1c}$, was independent of the presence of type 2 diabetes (Fig. 3).

The mean HOMA-IR values were significantly lower $(\mathrm{p}=0.003632)$ in subjects with the $\mathrm{GG}$ genotype ('high producers' of IL-10) in both groups, in which the expected anti-inflammatory response was strongest (Fig. 2). In contrast, the mean HOMA-B values 
a)

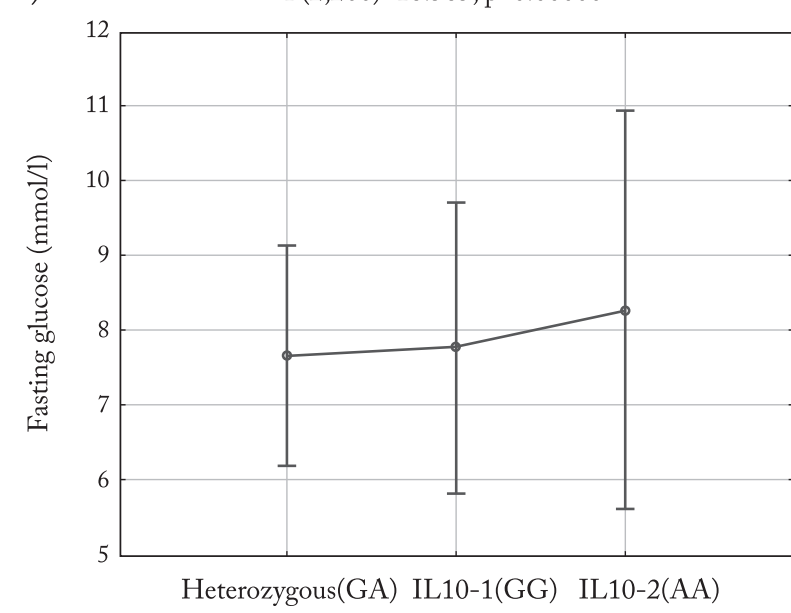

c)

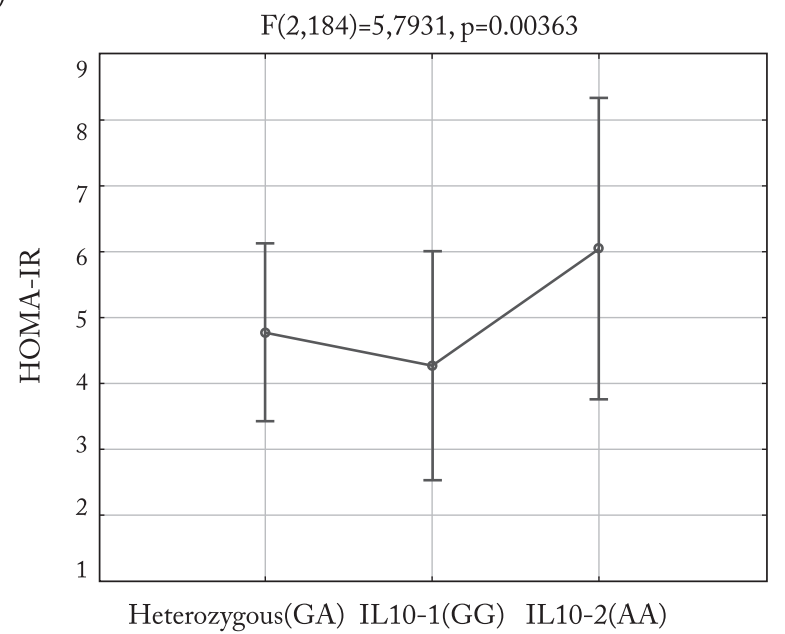

b)

$\mathrm{F}(2,219)=24.330, \mathrm{p}=0.00000$

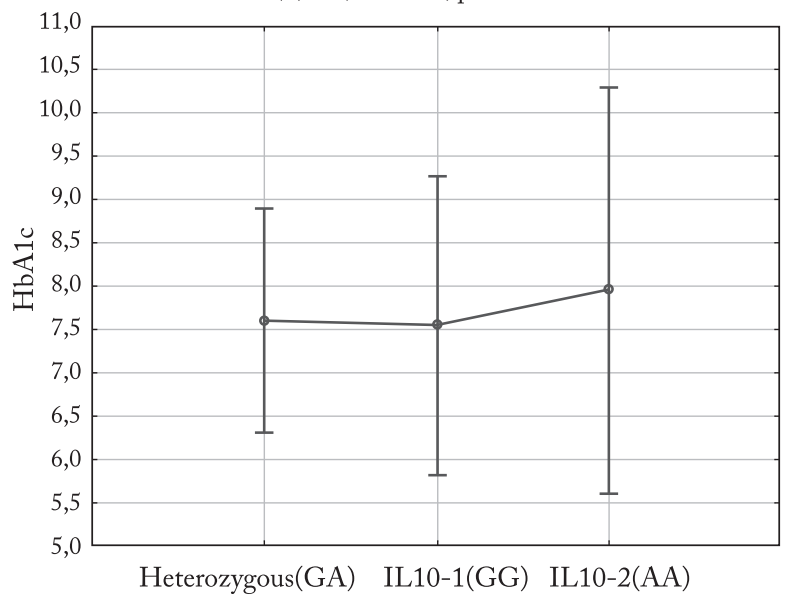

d)

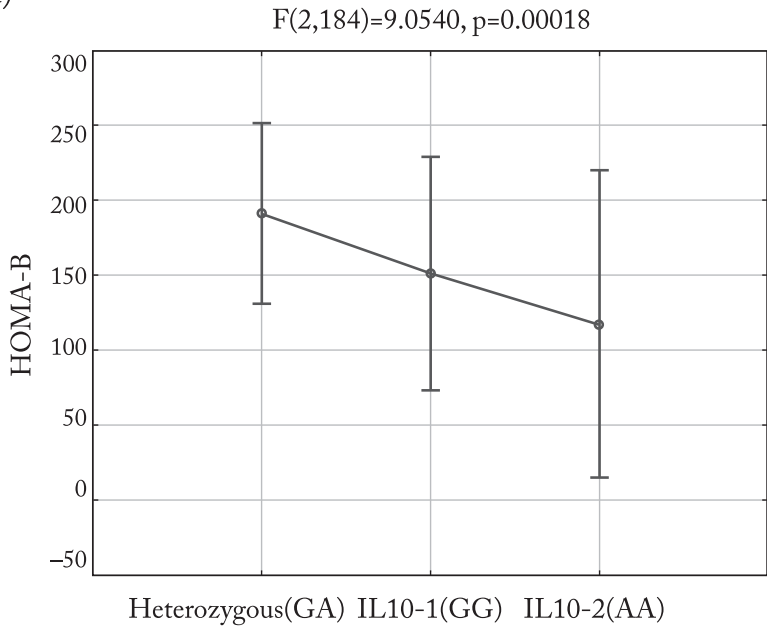

Fig. 2. Mean values of fasting glucose (a), HbA1c (b), HOMA-IR (c) and HOMA-B (d) according to IL-10 genotype.

were lowest $(p=0.000178)$ in subjects with the AA genotype ('low producers') with a diminished IL-10 anti-inflammatory response (Fig. 2). Again, the interaction effect was not statistically significant; that is, the effect of a specific IL-10 genotype on HOMA-IR and HOMA-B did not depend on the presence of type 2 diabetes (Fig. 3).

In order to investigate whether the described association of the IL-10 genotype and glucose metabolism parameters was a consequence of other risk factors (phenotype characteristics), analysis of the groups with different genotypes encompassing all subjects was performed in relation to sex, age and anthropometric characteristics (Table 2). There was no statistically significant difference between subjects with different genotypes for the IL-10-1082G/A polymorphism according to age, sex, waist circumference, or BMI.

In addition, analysis of chronic microvascular complications (24-hour protein and albumin excretion, proliferative and non-proliferative diabetic retinopathy, and diabetic polyneuropathy) in relation to a specific IL-10 genotype was performed (Table 3 ). There was no statistical significance in the development of microvascular complications between the groups with different IL-10 polymorphism genotypes.

\section{Discussion}

Insulin resistance and beta cell function have a key role in the pathogenesis of type 2 diabetes. Results of the UK Prospective Diabetes Study demonstrated that 

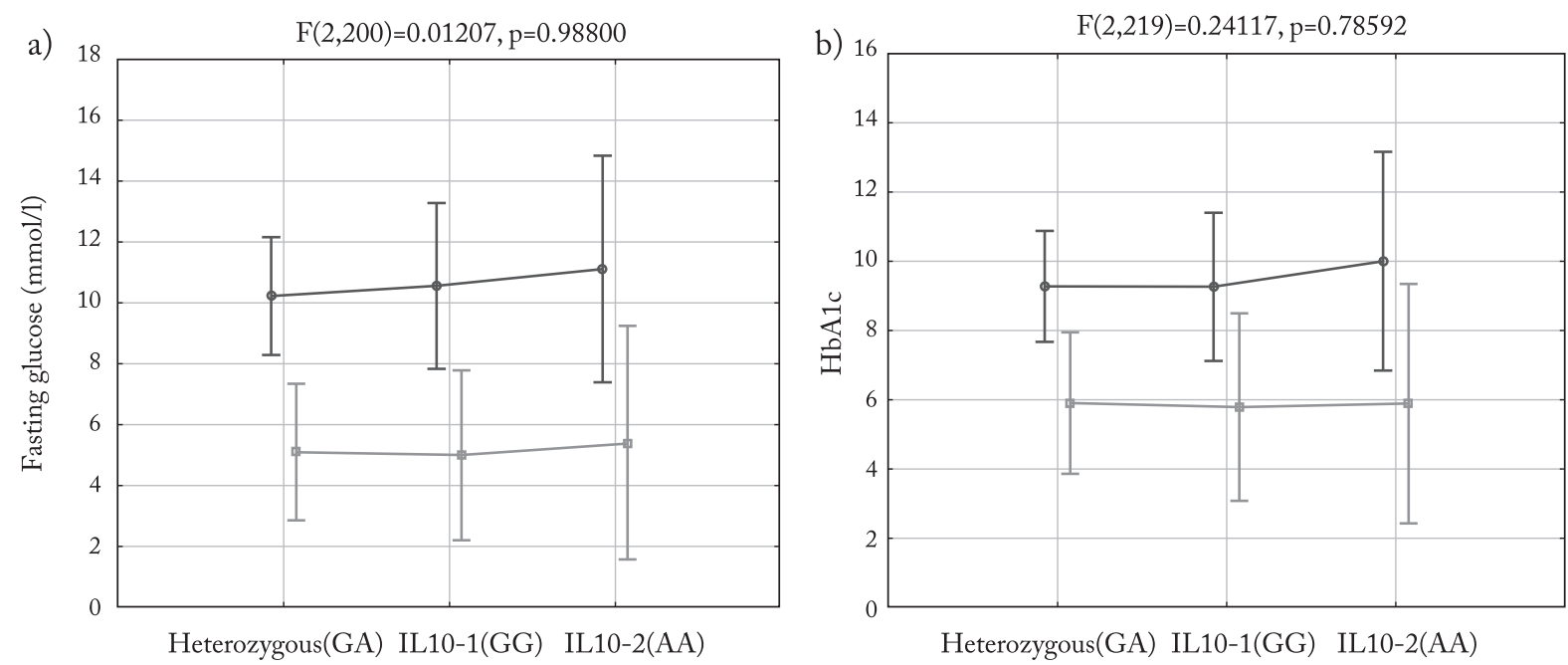

c)

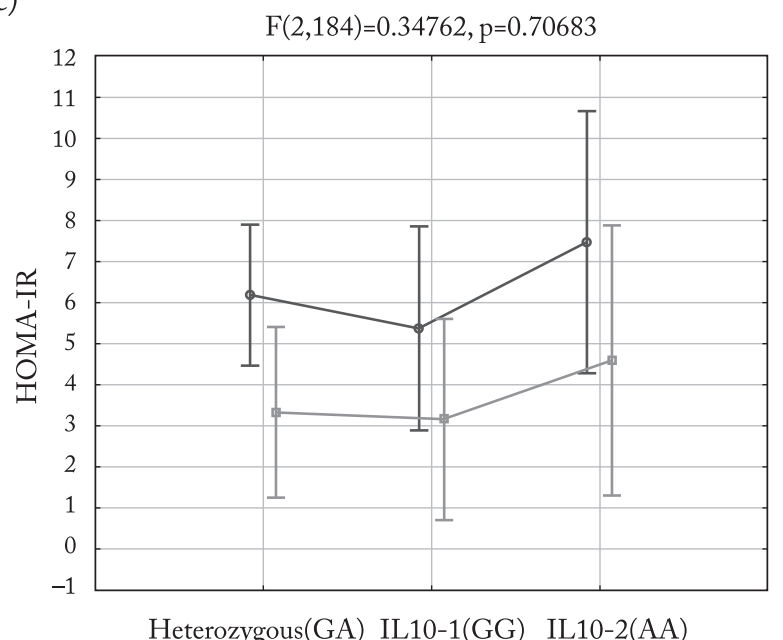

d)

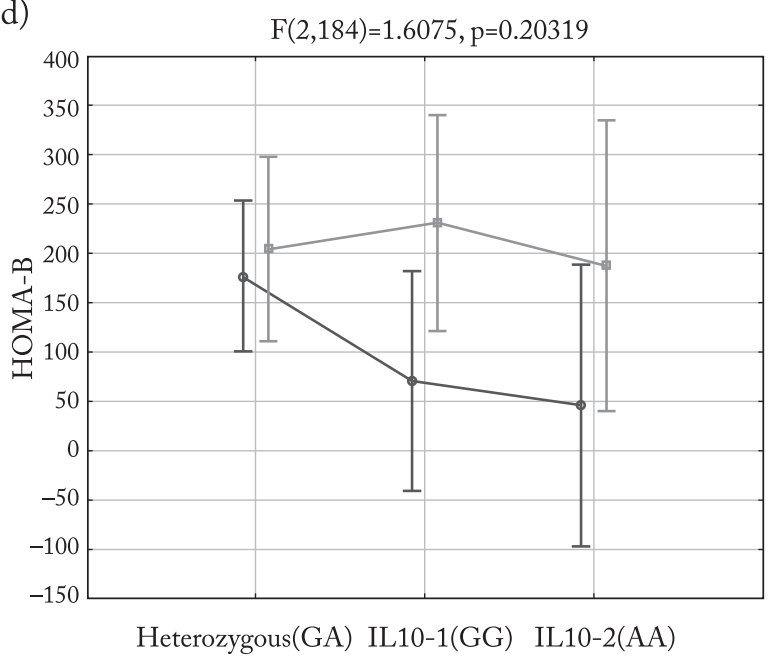

Ф Diabetic group
更 Control group

Fig. 3. Mean values of fasting glucose (a), HbA1c (b), HOMA-IR (c) and HOMA-B (d) according to both genotype and group.

impaired beta cell function was crucial for the development and progression of type 2 diabetes $^{21}$, while other studies implicated proinsulin secretion ${ }^{22}$, decline of beta cell mass ${ }^{23}$, and amyloid deposition ${ }^{24}$. In our study, patients with type 2 diabetes had higher HOMA-IR and lower HOMA-B values, clearly demonstrating two key elements of the pathophysiology of type 2 diabetes, i.e. insulin resistance and impaired beta cell function. Concentrations of basal insulin and $\mathrm{C}$-peptide were similar in both groups, probably as a result of compensatory insulinemia due to insulin resistance in patients with diabetes.
Current research in obese individuals indicates that the healthy obese population has low inflammatory activity as opposed to obese patients with metabolic syndrome ${ }^{25-27}$. These findings support our study where we found that specific parameters of inflammatory activity, such as leukocyte count, fibrinogen, serum albumin, and PAI-1 levels, were lower in control subjects than in patients with diabetes ${ }^{28-32}$. All markers of inflammation were increased in obese diabetic subjects except for CRP levels, where difference between the experimental and control groups was not statistically significant. Presumably, it was due to variations in the 
Table 2. Analysis of groups with different genotypes according to sex, age, waist circumference and body mass index (BMI)

\begin{tabular}{|l|l|l|l|l|}
\hline \multirow{2}{*}{ Phenotype characteristic } & \multicolumn{2}{|l|}{ Genotype -1082A/G IL-10 } & \multirow{2}{*}{-value } \\
\cline { 2 - 5 } & GG & GA & AA & \\
\hline *Age (years) & $59.4 \pm 9.4$ & $59.4 \pm 10.2$ & $60.1 \pm 8.0$ & 0.92 \\
Female: $\mathrm{n}(\%)$ & $40(55)$ & $82(64)$ & $24(63)$ & 0.41 \\
Male: $\mathrm{n}(\%)$ & $33(45)$ & $46(36)$ & $14(37)$ & \\
*Waist circumference $(\mathrm{cm})$ & $105.6 \pm 14.4$ & $105.5 \pm 14.4$ & $102.8 \pm 11.1$ & 0.54 \\
*BMI $\left(\mathrm{kg} / \mathrm{m}^{2}\right)$ & $33.2 \pm 5.9$ & $32.8 \pm 6.4$ & $32.7 \pm 5.9$ & 0.86 \\
\hline
\end{tabular}

*Data shown as mean $\pm \mathrm{SD}$; t-test, $\chi^{2}$-test

Table 3. 24-hour protein and albumin excretion, diabetic retinopathy and polyneuropathy according to IL-10 genotype

\begin{tabular}{|c|c|c|c|c|c|}
\hline \multirow{2}{*}{\multicolumn{2}{|c|}{ Diabetic complication }} & \multicolumn{3}{|c|}{ Genotype -1082A/G IL-10 } & \multirow{2}{*}{$\mathrm{p}$-value } \\
\hline & & GG & GA & AA & \\
\hline \multicolumn{2}{|c|}{ *24-h urine protein excretion $(\mathrm{mg} / \mathrm{L})$} & $168.37 \pm 167.4$ & $326.7 \pm 626.98$ & $211.0 \pm 262.65$ & 0.58 \\
\hline \multicolumn{2}{|c|}{ *24-h urine albumin excretion $(\mathrm{mg} / \mathrm{L})$} & $36.68 \pm 109.14$ & $111.2 \pm 293.4$ & $52.20 \pm 134.67$ & 0.69 \\
\hline Diabetic retinopathy & $\begin{array}{l}\text { Yes (\%) } \\
\text { No (\%) }\end{array}$ & $\begin{array}{l}16 \\
84\end{array}$ & $\begin{array}{l}11 \\
89\end{array}$ & $\begin{array}{l}12 \\
88 \\
\end{array}$ & 0.83 \\
\hline Diabetic polyneuropathy & $\begin{array}{l}\text { Yes (\%) } \\
\text { No (\%) }\end{array}$ & $\begin{array}{l}62 \\
38\end{array}$ & $\begin{array}{l}70 \\
30\end{array}$ & $\begin{array}{l}72 \\
28\end{array}$ & 0.72 \\
\hline
\end{tabular}

*Data shown as mean $\pm \mathrm{SD}$; t-test, $\chi^{2}$-test

sensitivity of CRP and circulating CRP levels between the groups.

Direct association of the IL-10-1082G/A polymorphism and type 2 diabetes remains elusive. Results of a meta-analysis published in 2013, which included 10 studies, demonstrated that the IL-10-1082G/A polymorphism was clearly associated with type 2 diabetes, but only in Asian, and not in European or African populations ${ }^{13}$. Our observation that the frequency of different IL-10 genotypes did not vary between the control and diabetic groups was in agreement with this analysis. However, when contemplating diabetes-related traits in all subjects (control and diabetic) of a specific genotype, it is clear that the HOMA-IR values were higher and HOMA-B values lower in the group with the AA genotype ('low producers') than in the groups with GG or GA genotypes. Our control group consisted of obese subjects without diabetes but the criteria we applied for diabetes exclusion (fasting glucose $<7 \mathrm{mmol} / \mathrm{L}, \mathrm{HbA} 1 \mathrm{c}<6.5 \%$ ) resulted in the inclusion of so-called 'intermediate' patients with prediabetes in our control group. Since this particular subset of patients has a higher risk of developing type 2 diabetes $^{33}$, we can speculate that the AA genotype of the IL-10 gene may occur at a higher frequency in patients with pre-diabetes than in healthy individuals. However, diabetes-related traits have not been fully established, thus influencing the final results of this study. The influence of SNP polymorphism in pre-diabetes should be investigated in further studies with a larger number of subjects.

Contrary to our results, a study performed by Scarpelli et al. in an Italian cohort found no association between IL-10-1082G/A and diabetes-related traits (fasting glucose, HOMA-B and HOMA-IR) ${ }^{19}$. This discrepancy may be attributed to ethnic variations regarding the prevalence of specific polymorphisms in the IL-10 gene, as our patients were recruited solely from eastern Croatia. Indeed, this is the first report on the frequency of the IL-10-1082G/A SNP in the Croatian population, and it is similar to previous reports for the European population (42.7\% and 46.9\%, respectively) ${ }^{13}$. However, in the study by Scarpelli et $a l .^{19}$, the link between AA genotype, fasting insulin 
and insulin resistance is reported with more prominent $-592 \mathrm{C} / \mathrm{A}$, but not the $-1082 \mathrm{G} / \mathrm{A}, \mathrm{IL}-10$ promoter polymorphism. Therefore, it is possible that in the Croatian population, the $-1082 \mathrm{G} / \mathrm{A}$ polymorphism is more prominent and contributes to the interindividual variation in BMI and insulin sensitivity.

In a study performed by Kolla et al., development of diabetic polyneuropathy was associated with high production of IL-10 (genotype $-1082 \mathrm{G} / \mathrm{G})^{16}$, while Lee et al. demonstrated that high concentrations of IL-10 negatively correlated with diabetic retinopathy ${ }^{18}$. However, we did not establish any difference in the development of microvascular complications between different IL-10 polymorphism genotypes, presumably due to a small sample size.

The present study had several limitations. The patient population was relatively small and recruited exclusively from eastern Croatia. This small patient population may have influenced study results, where IL10 polymorphism genotypes were associated with diabetes-related traits but not with diabetes or its microvascular complications. Furthermore, standard statistical analysis of the secondary phenotype data in case-control studies can be misleading since the association between a secondary phenotype and a genetic variant in the case and control groups can be quite different from their association in the general population, requiring a novel approach in statistical analysis ${ }^{34}$. In addition, since this was a cross-sectional study, disease outcome and prognosis in relation to a specific genotype is still unknown. Thus, a large-scale, long-term, prospective, population-based study with different ethnicities is required to establish whether a relationship between polymorphisms in the IL-10 gene and type 2 diabetes actually exists and whether it affects the prognosis of type 2 diabetes and development of microvascular complications.

\section{Conclusions}

In conclusion, obese patients with type 2 diabetes showed an increased inflammatory activity when compared to obese non-diabetic controls. We could not show the association between the IL-10-1082G/A SNP genotypes and development of type 2 diabetes and microvascular complications. However, we established a clear link between the IL-10-1082G/A polymorphism and diabetes-related traits, therefore specific genotypes (high producers $v s$. low producers) had a distinct impact on diabetes-related traits in all subjects.

\section{Acknowledgments}

The authors would like to thank Department of Endocrinology, Osijek University Hospital Centre and Laboratory of DNA Analysis. We thank Nataša Šarlija for providing help and guidance in statistical analysis. This research was supported by the Ministry of Science, Education and Sports of the Republic of Croatia, grant number 219-0000000-3362.

\section{References}

1. Muller S, Martin S, Koenig W, Hanifi-Moghaddam P, Rathmann W, Haastert B, et al. Impaired glucose tolerance is associated with increased serum concentrations of interleukin- 6 and co-regulated acute-phase proteins but not TNF- $\alpha$ or its receptors. Diabetologia. 2002;45:805-12. doi: $10.1007 / \mathrm{s} 00125-002-0829-2$

2. Temelkova-Kurktschiev T, Siegert G, Bergman S, Henkel E, Koehler C, Jaross W, et al. Subclinical inflammation is strongly related to insulin resistance but not insulin secretion in high risk population for diabetes. Metabolism. 2002;51:743-9.

3. Feinstein R, Kanety H, Papa MZ, Lunenfeld B, Karasik A. Tumor necrosis factor- $\alpha$ suppresses insulin-induced tyrosine phosphorylation of insulin receptor and its substrates. J Bio Chem. 1993;268:26055-8.

4. Shoelson SE, Lee J, Goldfine AB. Inflammation and insulin resistance. J Clin Invest. 2006;116:1793-801. doi: 10.1172/JCI29069

5. Otero M, Lago R, Lago F, Casanueva FF, Dieguez C, GomezReino JJ, Gualillo O. Leptin, from fat to inflammation: old questions and new insights. FEBS Lett. 2005;579:295-301. doi: $10.1016 /$ j.febslet.2004.11.024

6. Donath MY, Storling J, Maedler K, Mandrup-Poulsen T. Inflammatory mediators and islet beta-cell failure: a link between type 1 and type 2 diabetes. J Mol Med. 2003;81:455-70.

7. Ellingsgaard H, Ehses JA, van Lommel L, Schuit FC, Donath MY. IL-6 regulates alpha-cell mass and function. Diabetologia. 2006;49 (Suppl 1):282-3.

8. Hong EG, Ko HJ, Cho YR, Kim HJ, Ma Z, Yu TY, et al. Interleukin-10 prevents diet-induced insulin resistance by attenuating macrophage and cytokine response in skeletal muscle. Diabetes. 2009;58(11):2525-35.doi: 10.2337/db08-1261

9. Van Exel E, Gussekloo J, de Craen AJ, Frölich M, BootsmaVan Der Wiel A, et al. Low production capacity of interleukin-10 associates with the metabolic syndrome and type 2 diabetes: the Leiden 85-Plus Study. Diabetes. 2002;51:1088-92.

10. Snijder MB, Heine RJ, Seidell JC, Bouter LM, Stehouwer CD, Nijpels $\mathrm{G}$, et al. Associations of adiponectin levels with incident impaired glucose metabolism and type 2 diabetes in older men 
and women: the HOORN study. Diabetes Care. 2006;29 (11):2498-503. doi: $10.2337 / \mathrm{dc} 06-0952$

11. Menzaghi C, Trischitta V, Doria A. Genetic influences of adiponectin on insulin resistance, type 2 diabetes, and cardiovascular disease. Diabetes. 2007;56(2):1198-209. doi: $10.2337 / \mathrm{db} 06-0506$

12. Hara K, Horikoshi M, Yamauchi T, Yago H, Miyazaki O, Ebinuma $\mathrm{H}$, et al. Measurement of the high molecular weight form of adiponectin in plasma is useful for the prediction of insulin resistance and metabolic syndrome. Diabetes Care. 2006;29(6):1357-62.

13. Hua Y, Shen J, Song Y, Xing Y, Ye X. Interleukin-10-592C/A, $-819 \mathrm{C} / \mathrm{T}$ and $1082 \mathrm{~A} / \mathrm{G}$ polymorphism with risk of type $2 \mathrm{dia}-$ betes mellitus: a HuGE review and meta-analysis. PLoS One. 2013;8(6):e66568.

https://doi.org/10.1371/journal.pone.0066568

14. Vasseur F, Helbecque N, Dina C, Lobbens S, Delannoy V, Gaget S, et al. Single- nucleotide polymorphism haplotypes in both proximal promoter and exon 3 of the APM1 gene modulate adipocyte-secreted adiponectin hormone levels and contribute to the genetic risk for type 2 diabetes in French Caucasians. Hum Molecul Genet. 2002;11(21):2607-14.

15. Han LY, Wu QH, Jiao ML, Hao YH, Liang LB, Gao LJ, et al. Associations between single-nucleotide polymorphisms $(+45 \mathrm{~T}>\mathrm{G},+276 \mathrm{G}>\mathrm{T},-11377 \mathrm{C}>\mathrm{G},-11391 \mathrm{G}>\mathrm{A})$ of adiponectin gene and type 2 diabetes mellitus: a systematic review and meta-analysis. Diabetologia. 2011;54(9):2303-14. doi: 10.1007/s00125-011-2202-9

16. Kolla VK, Madhavi G, Pulla Reddy B, Srikanth Babu BM, Yashovanthi J, Valluri VL, Ramesh J, Akka J. Association of tumor necrosis factor alpha, interferon gamma and interleukin 10 gene polymorphism with peripheral neuropathy in South Indian patients with type 2 diabetes. Cytokine. 2009;47(3):173-7. doi: 10.1016/j.cyto.2009.06.007

17. Bostrom MA, Freedman BI, Langefeld CD, Liu L, Hicks PJ, Bowden DW. Association of adiponectin gene polymorphism with type 2 diabetes in an African American population enriched for nephropathy. Diabetes. 2009;58(2):499-504. doi: $10.2337 / \mathrm{db} 08-0598$

18. Lee JH, Lee W, Kwon OH, Kim JH, Kwon OW, Kim KH, Lim JB. Cytokine profile of peripheral blood in type 2 diabetes mellitus patients with diabetic retinopathy. Ann Clin Lab Sci. 2008;38:361-7.

19. Scarpelli D, Cardellini M, Andreozzi F, Laratta E, Hribal ML, Marini MA, Tassi V, Lauro R, Perticone F, Sesti G. Variants of the interleukin-10 promoter gene are associated with obesity and insulin resistance but not type 2 diabetes in Caucasian Italian subjects. Diabetes. 2006;55:1529-33.

https://doi.org/10.2337/db06-0047

20. Tagore A, Gonsalkorale WM, Pravica V, et al. Interleukin-10 (IL-10) genotypes in inflammatory bowel disease. Tissue Antigens. 1999;54:386-90.

21. UK Prospective Diabetes Study (UKPDS) Group. UK Prospective Diabetes Study 16. Overview of 6-year therapy of type 2 diabetes: a progressive disease. Diabetes. 1995;44:1249-58.
22. Mykkanen L, Haffner SM, Kuusisto J, Pyorala K, Hales CN, Laakso M. Serum proinsulin levels are disproportionally increased in elderly prediabetic subjects. Diabetologia. 1995; 38:1176-82.

23. Kloppel G, Lohr M, Habich K, Oberholzer M, Heitz PU. Islet pathology and the pathogenesis of type 1 and type 2 diabetes mellitus revisited. Surv Synt Pathol Res. 1985;4:110-25.

24. SakoY, Grill VE. A 48-hour lipid infusion in the rat time dependently inhibits glucose induced insulin secretion and B cell oxidation through a process likely coupled to fatty acid oxidation. Endocrinology. 1990;127:1580-9.

25. Karelis AD, Faraj M, Bastard JP, et al. The metabolically healthy but obese individuals present a favorable inflammation profile. J Clin Endocrinol Metab. 2005;90:4145-50. doi: 10.1210/jc.2005-0482

26. Koster A, Stenholm S, Alley DE, et al. Body fat distribution and inflammation among obese older adults with and without metabolic syndrome. Obesity. 2010;18:2354-61. doi: $10.4161 / 21623945.2014 .978662$

27. Doumately AP, Bentley AR, Zhou J, Huang H, Adeymo A, Rotimi CN. Paradoxical hyperadiponectinemia is associated with metabolically healthy obese (MHO) phenotype in African Americans. J Endocrinol Metab. 2012;2:51-65. doi: 10.4021/jem95W

28. Lynch LA, O’Connel JM, Kwasnik AK, Cawood TJ, O'Farrelly $\mathrm{C}$, O'Shea DB. Are natural killer cells protecting the metabolically healthy obese patient? Obesity. 2009;17:601-5. doi: 10.1038/oby.2008.565

29. Schmidt MI, Duncan BB, Sharrett AR, Lindberg G, Savage PJ, Offenbacher S, Azambuja MI, Tracey RP, Heiss G. Markers of inflammation and prediction of diabetes mellitus in adults (Atherosclerosis Risk in Communities study): a cohort study. Lancet. 1999;353:1649-52.

30. Duncan BB, Schmidt MI, Offenbacher S, Wu KK, Savage PJ, Heiss G. Factor VIII and other hemostasis variables are related to incident diabetes in adults: the Atherosclerosis Risk in Communities (ARIC) study. Diabetes Care. 1999;22:767-72.

31. Bahceci M, Gokal P, Pachceci S, Tuzcu A, Atmaca S, Arikan S. The correlation between adiposity and adiponectin, tumor necrosis factor alpha, interleukin-6 and high sensitivity C-reactive protein levels. Is adipocyte size associated with inflammation in adults? J Endocrinol Invest. 2007;30:210-4.

32. Festa A, D'Agostino R, Tracey RP, Haffner SM. Elevated levels of acute phase proteins and plasminogen activator inhibitor-1 predict the development of type 2 diabetes: the Insulin Resistance Atherosclerosis Study. Diabetes. 2002;51:1131-7.

33. Genuth S, Alberti KG, Bennet P, et al. Expert Committee on the Diagnosis and Classification of Diabetes Mellitus. Follow up report on the diagnosis of diabetes mellitus. Diabetes Care. 2003;26:3160-7.

34. Lin DY, Zeng D. Proper analysis of secondary phenotype data in case-control association studies. Genet Epidemiol. 2009;33 (3):256-65. doi: 10.1002/gepi.20377 
Sažetak

POVEZANOST POLIMORFIZMA GENA ZA INTERLEUKIN-10 (-1082G/A)
S TIPOM 2 ŠEĆERNE BOLESTI I MIKROVASKULARNIM KOMPLIKACIJAMA
U HRVATSKOJ POPULACIJI

\section{S. Canecki-Varžić, I. Prpić-Križevac, S. Mihaljević, I. Bilić-Ćurčić, T. Alkhamis, J. Wagner, I. Škrlec i J. Barbić}

Smanjena sekrecija protuupalnog citokina interleukina (IL)-10 opisana je u debljini, metaboličkom sindromu i tipu 2 šećerne bolesti (T2ŠB). Međutim, nije utvrđeno može li intenzitet imunog odgovora tijekom kronične upale utjecati na razvoj i/ili progresiju dijabetesa kao i razvoj mikrovaskularnih komplikacija. Cilj ove studije bio je istražiti povezanost polimorfizma gena (SNP) -1082G/A za IL-10 s razvojem T2ŠB i kroničnih komplikacija. DNK za genotipizaciju se ekstrahirala iz krvnih stanica 240 adipoznih ispitanika koji su podijeljeni u dvije skupine: u eksperimentalnoj skupini bilo je 144 bolesnika s T2ŠB, a u kontrolnoj skupini 96 ispitanika usklađenih prema spolu i dobi. U skupini s T2ŠB nađene su više vrijednosti leukocita $(\mathrm{p}=0,012)$, fibrinogena $(\mathrm{p}=0,049)$ i inhibitora aktivacije plazminogena-1 (PAI-1) $(\mathrm{p}=0,009)$ te niže koncentracije albumina $(\mathrm{p}=0,001)$ nego u kontrolnoj skupini. Nije bilo statističke razlike u frekvencijama -1082G/A polimorfizma gena za IL-10 ( $\mathrm{p}=0,654)$. Kada su se gledali ishodi za specifični genotip u svih ispitanika, ispitanici s homozigotnim genotipom (AA) imali su značajno više koncentracije glukoze natašte $(p<0,000001)$, HbA1c $(p<0,000001)$ i HOMA-IR $(\mathrm{p}=0,003632)$ te niži indeks HOMA-B $(\mathrm{p}=0,000178)$ u odnosu na ispitanike s genotipovima GG i GA. Nije bilo razlike u genotipovima polimorfizma IL-10 gena i razvoja nefropatije, retinopatije i polineuropatije. U zaključku, pretili bolesnici s T2ŠB imali su pojačanu upalnu aktivnost u usporedbi s pretilim ispitanicima bez šećerne bolesti. Nije utvrđena povezanost polimorfizma IL-10 i razvoja T2ŠB kao ni razvoja mikrovaskularnih komplikacija. Međutim, ishodi povezani s dijabetesom jasno su povezani sodređenim genotipom IL-10.

Ključne riječi: Dijabetes tip 2; Upala; Interleukin-10; SNP-1082G/A; Mikrovaskularne komplikacije 